\title{
The Contribution of Locus of Control to Academic Procrastination of Islamic Education Management Students in Indonesia
}

Received: $8^{\text {th }}$ February 2017; Revised:15 ${ }^{\text {th }}$ February 2017; Accepted: $31^{\text {th }}$ March 2017

Permalink/DOI: http://dx.doi.org/10.15548/jt.v24i1.260

\section{Juliana Batubara}

Institut Agama Islam Negeri Imam Bonjol

Padang, Indonesia

E-mail: batubara.juliana@yahoo.co.id

\begin{abstract}
This study aimed to describe the locus of control and academic procrastination, and investigate whether there is significance contributions of locus of control on student academic procrastination. This research was conducted by the Ex post-facto method was used in this study, where the data taken from two set of questionnaires. Proportional Stratified Random Sampling was used. There were 107 students involved this study. The results showed that the locus of control is in average level, meanwhile, and the students' academic achievement was high. The study also showed that there is a significant contribution between the locus of control on students' academic procrastination. The article concludes that the importance that locus control for procrastination research, and with suggestions for educators who work with students who are adversely affected by procrastination.
\end{abstract}

Keywords: Locus of control, academic procrastination, education management

How to Cite: Batubara, J. (2017). The contribution of locus of control to academic procrastination of Islamic education management students in Indonesia. Al-TaLim Journal, 24(1). doi: http://dx.doi.org/10.15548/jt.v24i1.260

\section{INTRODUCTION}

Islamic education management department is one of the majors are in the Faculty of Islamic Education and Teacher Training at the State Islamic Institute Imam Bonjol Padang. This department gained duties and responsibilities for childbirth educators are professionals. It is consistent with the vision of Islamic education management department to be a developer of science institution and professionals in guidance and counseling services. It would provide relief and alleviation of problems for individuals both in the school/ Madrasah and wider community in order to develop optimally, independent and happy. To achieve this vision can be described through Islamic education management department mission is to (1) carry out the learning process effective, efficient and innovative in preparing educators /Islamic counseling professionals in school settings/ Madrasah; (2) increase community service-based counseling in order to improve human resources; (3) increase the research activities in the field of counseling; (4) provide learning facilities and infrastructure to carry out exercises in the field of counseling; (5) provide academic services and administrative quality for the entire academic community; (6) establish good cooperation with other parties to 
improve human resources in the field of counseling; and (7) improve the quality of study programs through the gradual and sustainable development program in aspects of education, human resources and infrastructure.

In line with its vision and mission, the purpose of the Islamic education management department is to produce scholars of Islamic education who have basic skills in the field of professional guidance and counseling. To achieve vision, mission and goals of the department is very importance to be considered. It is stated in strategic plan that various strategies should be implemented to achieve the learning goal. It can be done through improving the quality of human resources, students' learning, research, community services, facilities and infrastructure, culture and partnership. In addition, students play an important role, especially in the spirit, activity and hard work in the learning process to achieve optimal results in realizing the vision, mission and objectives. It can be seen from the activity/ learning activities of students qualified.

One of the activities the teaching/ learning activities of students is to work on a task and collect assignments on time. But conditions in the field students exhibit behaviors that support learning activities less well. Based on observations of the student of Islamic education management department in March-April 2015 seen $40 \%$ to $50 \%$ of these students had less behavioral support learning activities well as habits often procrastinate (academic procrastination) in initiating and completing tasks assigned by the lecturer, often late in collecting duties and even requested that the collection time is extended tasks, no tasks are made carelessly, students late for class when the lesson began, refused and asked for the exam be postponed, even the opportunity provided lecturers to read or create a task squandered out of the classroom to the cafeteria, playing in the field and other activities that are less useful at the time. This shows lack of habits; procrastinate in doing the task (academic procrastination). If this is sustained it will have an impact on student learning outcomes.

One of factors influence on learning activities is a psychological condition. It includes the basic capabilities common/ intelligence, aptitude, interest, motivation, mastery of skills, learning styles, locus of control, aspiration/ aspiration, perseverance, concentration, memory, self-esteem, maturity, and perception (Eccles \& Roeser, 2009; Joseph \& Joseph, 2001).

One of the internal factors that affect the learning activities is of interest. Interest is a taste and flavor more like the attachment to a matter or activity, without being told (Syah, 2012). Interest is essentially a relationship yourself with something outside them. Students who have an interest in lecturing duties tend to give greater attention, so that the student is able to do the work on time, whereas students who are less interested in the task of lecturing it will likely have less attention to procrastinate in completing tasks lectures. Besides that talent had a role in the process of student learning activities. Teaching the appropriate field will enlarge the talent someone successful in learning. Therefore, for students who occupy the majors according to the talents tend to be positive in the learning process (Jackson, Weiss, Lundquist, \& Hooper, 2003).

Other internal factors that affect learning is the locus of control, which is one significant variable to predict adjustment to the demands of students and academic activities (Ajzen, 2002). Associated with the concept of internal-external locus of control, can be explained that students who have an external locus of control tend to be less effort, less persistent, passive, and surrender to fate / destiny. Therefore, it would result in a lecture task that should be done on time actually delayed doing it for more surrender to fate / destiny. Conversely, students who have an internal locus of control, tend to try to persevere and persevere, because they feel and believe that anything they earn is the result itself, which is the result of effort and 
hard work, ability, and skills they possess. Confidence that accompanies such behavior and actions will result in high spirit with the task on time (Mutai, 2014).

Based on the above phenomenon, researchers want to know how big contribution of locus of control on students' academic Procrastination. Therefore, researchers feel the need to do research with the title "Contributions Locus of Control on Academic Procrastination Students Islamic Education Management Department Faculty of Islamic Education and Teacher Training IAIN IB Padang”.

\section{METHOD}

Ex post facto method was used to investigate the events that have occurred and then trace backward to find the factors that affect learning. This study uses correlation approach that aims to determine how much the contribution locus of control (X) to the students' academic Procrastination (Y). The populations in this study were 355 students in Islamic education management department in 2014, 2013 and 2012. Stratified proportional random sampling was used where 107 students involved in this study. Data was collected through a questionnaire with a scale of five, and data analysis using statistical approaches regression techniques (Riduwan, 2006).

\section{RESULT AND DISCUSSION}

\section{Variable Description of Locus of Control and Student Academic Procrastination}

Description locus of control students in Islamic education management department can be seen in table 1 .

Table 1.Description Locus of control and the Student Academic Procrastination

\begin{tabular}{clcc}
\multicolumn{4}{c}{ Academic Procrastination } \\
\hline No & \multicolumn{1}{c}{ Variable } & Mean & SD \\
\hline 1. & Locus of control (X) & 80.59 & 8.93 \\
2. & $\begin{array}{l}\text { Academic } \\
\text { procrastination (Y) }\end{array}$ & 68.25 & 8.91 \\
\hline
\end{tabular}

Based on table 1 it can be seen that the locus of control students of MPI FTK medium is classification. It can be seen from the acquisition of a mean of 80.59 (with the ideal score of 120) and a standard deviation of 8.93. In variable Islamic education management students of academic procrastination is high. It can be seen from the acquisition of a mean of 68.25 (with the ideal score 95) and a standard deviation of 8.91.

Based on the results of data processing that has been done, it can be concluded that the data meets the requirements for the regression analysis is to test for normality and linearity test (Riduwan, 2006).

\section{Contribution of Locus of Control on Students' Academic Procrastination}

Contributions locus of control to student academic procrastination MPI FTK can be seen in Table 2 .

Table 2.Correlation analysis

\begin{tabular}{cccc}
\hline No & Variable & R & R Square \\
\hline 1. & $\mathrm{XY}$ & .143 & .021 \\
\hline
\end{tabular}

According to the table 2 can be seen that the variable XY R value of 0.143 and the value of r-quare are 0.021 . This shows that the contribution of locus of control on student academic procrastination is by $2.1 \%$, while the remaining $97.9 \%$ is influenced by other variables not included in this research study.

The survey results revealed that the locus of control levels were medium and students' academic procrastination is high. The medium achievement level of student's locus of control is to be improved and the high performance Islamic education management students' academic procrastination is a thing that needs to be improved for the sake of self-development and especially the academic development of students in the future. This is important, because the success of self-development, academic success and career success of students influenced by the variables. 


\section{Locus of Control Student Islamic Education Management Department IAIN IB Padang}

Based on the research that has been described above, students' locus of control is classified in the category. Locus of control is one factor that contributes to student academic procrastination. Correlation locus of control on student academic procrastination conform to the theory (Mooney, Sherman, \& Presto, 1991); (Covington, 2007). This happens because the locus of control related to trust students in accordance with the tendency of their locus of control. Confidence of individuals against the causes of success and failure is important, means to understand the behavior associated with achieving success.

Their relationship locus of control with academic procrastination occurs because individuals have locus internally they feel and believe that what they earn is the result itself, which is the result of effort and hard work, ability, and skill they have (Covington, 2007). Confidence that accompanies such behavior and actions $t$ will result in high spirit with the task on time. Students who have an internal locus of control, tend to try to persistent and diligent (Cooper, 1999). Conversely, individuals who have a locus external feel and believe that something they earn more determined by something outside himself, as luck /fate, luck, chance or due to the influence of others (Covington, 2007).

To modify and / or develop student learning activities related to locus of control, presumably education needs to focus on the attribution of success or failure of the business factors, and not on the capability especially in fate / destiny and chance factors. For comparison, Japan as a country that successfully compete with other countries in the economic and industrial fields that allegedly because of the quality of education, more emphasis on effort rather than ability attributions. Japanese education emphasizes cooperation rather than competition, therefore, not much chance of attributing the causes of success or failure in the ability factor, because the attribution to the ability usually develops in a competitive situation (Ardhana, 1990). Presumably, if education is more oriented towards cooperation rather than competition and focuses more effort than ability attributions, it is expected that students' behavior will be better, and in turn will increase their learning achievements.

Based on the results of the research efforts is changing trends locus of control from an external student becomes internal. This can be done through counseling services with Rational Emotive approach, in addition to the situations and circumstances that require their responsibilities to students.

\section{Academic Procrastination of MPI Students at FTK IAIN IB Padang}

The findings showed that students' academic procrastination of MPI FTK IAIN IB Padang at the high category. Academic procrastination is a specific behavior that includes: a) a delay element behavior involving either to start or complete a task or activity. b) Generate the consequences of other more distant, such delay or failure to complete the task in the task. c) Involves a task perceived by the perpetrator delay as an important task to be done, such as office work or school assignment household tasks. d) Produce an unpleasant emotional state, such as feelings of anxiety, guilt, anger, and panic.

Some things that can lead to academic procrastination, namely: (1) Anxiety or fear. This belief is based on the belief that irrational. Individual doubted her on a plane. This belief causes one delaying the completion of his task. (2) It is difficult making a decision. Individuals sometimes have difficulty deciding which tasks should be done in advance or how the completion of a task. (3) Rebellion (Rejection). Individuals do Procrastination academic as a refusal to complete a task; this is done consciously and knows the consequences. (4) Less assertive. Less assertive is associated with the passive attitude of a delay task. When students do not 
want to seek the help of others to complete the task, the task is not done or completed tasks consequently approaching deadline was resolved by not optimal. (5) Fear of failure. Fear of failure is an irrational belief, people who fear failure to defer to the task as an escape from anxiety. (6) Want something in a state Prefect / perfectionist. Delay the task of making the delay in the hope of obtaining a lot of time to complete its work (Eilam \& Aharon, 2003; Ramsden, 2003).

In addition to the above-described factors that influence student academic procrastination can also be categorized into three types, namely:

1. Characteristics perceived task college student as pleasant task or boring influence college student for delay completion task. Characteristics a tedious task on generally make college student do delay to something task.

2. Individuals who have trust Low selfesteem will tend do procrastination. This constitutes factor personality procrastinator.

3. Factor situational, presence disruption or distracts environmental influences someone for delay jobs. (Rakes \& Dunn, 2010; (Richardson, Abraham, \& Bond, 2012)

According Richardson et al. (2012), there are two main factors affecting the delay of the tasks are:

1. Internal factors are factors within the individual that helped shape the behavior and postponement of tasks which include physical and psychological factors.

2. External factors, namely the factor of the task (task overload) demanding a settlement at the same time. Multitasking draining someone, thus experiencing fatigue and unable to complete the task.

Seeing the two factors above, it appears that previous internal factors more opportunity on the behavior of delays to the task, though not impossible internal and external factors interact with each other, so duties would worsen.

Knaus (2010) states "Time management alone is frequently insufficient to Decrease procrastination, especially when the procrastination habit process is complicated by personal-development matters such as perfectionism anxiety, or depression". Delays to the task occurs because weak time management, concentration is difficult, and anxiety, negative beliefs, personal problems, getting a tedious task, unrealistic expectations and a perfectionist as well as fear and failure.

Student academic procrastination is a form of behavior that delays in the execution of an activity (Skowronski \& Mirowska, 2013). Behavior of this delay is the result of an error in their thinking and irrational thoughts on tasks such as fear of failure in the completion of a task or job in day-to-day.

Someone who does academic procrastination sometimes does not intend to avoid or do not want to know the task that it faces. However, these students just procrastinate to do so take time in the execution of these tasks and maximum results in previously unattainable expect it properly.

\section{Contribution of Locus of Control on Student Academic Procrastination}

The findings show that the contribution of locus of control on student academic procrastination is by $2.1 \%$, while the remaining $97.9 \%$. Effective contribution is likely to be caused by two factors. First, because of the many variables that affects student academic procrastination. The number of variables that affect student academic procrastination causes the diminishing role of certain variables. This occurs because each tap between variables.

In light of the results of this study, the effective contribution is thought to occur because in addition to the many variables that affects the academic procrastination, as well as a mutual attraction or mutual press between variables. 
Learning is an activity that process, and an element that is fundamental to every organization of the type and level of education. The success or failure of education goals relies heavily on student learning experience. (Ardi, Hariko, \& others, 2014). Overview interconnectedness of various variables is illustrated in Figure 1.

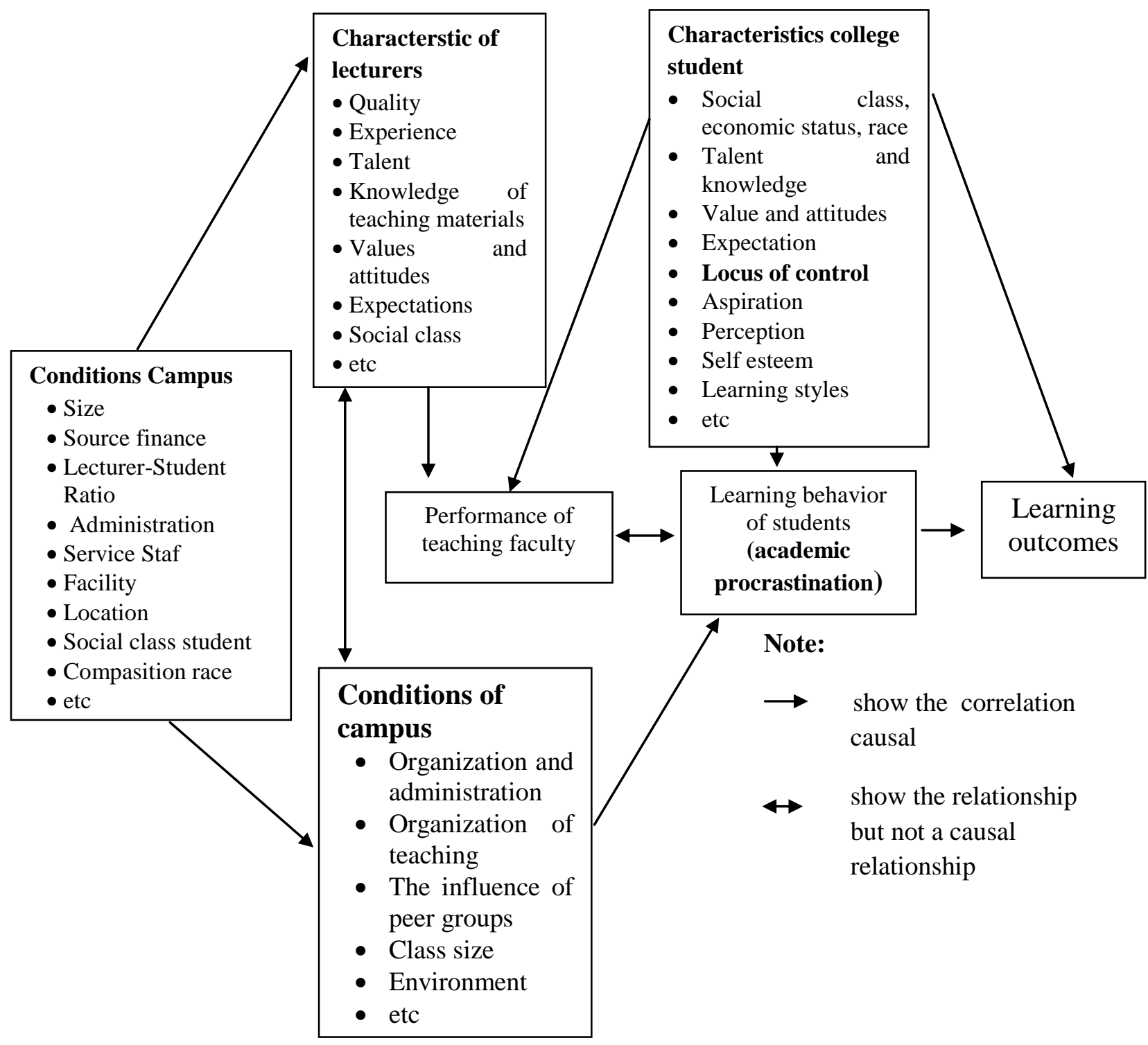

Figure 1. The Variables Related to Teaching and Student Learning Outcomes. Source: (Elliott, Kratochwill, Littlefield, \& Travers, 1996)

Based on the figure above, it shows that one of the internal factors that influence the behavior of students in learning (academic procrastination) is the locus of control. Locus of control is a significant variable to predict adjustment to the demands of students and academic activities (Friedlander, Reid, Shupak, \& Cribbie, 2007). Students who have an external locus of control tend to be less effort, less persistent, passive, and surrender to fate / destiny. Therefore, it would result in a lecture task that should be done on time actually delayed doing it for more surrender to fate / destiny. Conversely, students who have internal locus of control tend to try to persistent and diligent, because they feel and believe that what they earn is the result itself, which is the result of effort and hard work, ability, and skills they. Confidence that accompanies such behavior and actions will 
result in high spirit with the task on time. This will affect the learning achievement they would earn. Learning achievement is the level of student success in mastering the subject matter. Learning achievement is a change in terms of proficiency behavior or ability to grow for some time and was not caused by the growth process, but for their learning situation, the embodiment in the form of learning outcomes can be the problem solving or skills that can be measured (Lepine, Colquitt, \& Erez, 2000).

Decreased levels of learning achievement one of the reasons for not maximum in every task given by lecturers, ditching and cannot use time well. This comes as a result of their locus of control. Locus of control is one's perception of the causes of success or failure in carrying out the work.

\section{CONCLUSIONS AND RECOMMENDATION}

Based on the results of research on the contribution of locus of control on academic procrastination students Islamic education management at IAIN Imam Bonjol Padang can be concluded as follows: (1) On the average level of the locus of control majors Islamic education management at IAIN Imam Bonjol Padang classified as medium and academic procrastination student of Islamic education management at IAIN Imam Bonjol Padang was high. (2) Locus of control has a significant contribution to the Students' academic procrastination.

Based on the conclusion of the study put forward some suggestions as follows: (1) To lecturers PA advisable to carry out tasks in accordance with the roles, responsibilities and authority of each in order to build and develop student learning activities. In addition, the faculty can collaborate with UPBK in alleviating the problems of his foster student so that the effective life everyday to run well. The efforts made by to be internal locus of control students, by providing the opportunity and put the student in a position that calls for the authority and responsibility, applying SCR and TREB. (2) To the researchers suggested that further enrich the study by taking a variable other than the locus of control, but it was able to follow up on these results with the model leads to the development of services to students in developing student learning activities.

\section{REFERENCES}

Ajzen, I. (2002). Perceived behavioral control, self-efficacy, locus of control, and the theory of planned Behavior1. Journal of Applied Social Psychology, 32(4), 665-683.

Ardhana, M. M. (1990). Microbial Ecology and Biochemistry of Cocoa Bean Fermentation. University of New South Wales.

Ardi, Z., Hariko, R., \& others. (2014). Gambaran Kegiatan Belajar Siswa Sumatera Barat. Retrieved from http://digilib.unimed.ac.id/4793/

Cooper, D. E. (1999). Existentialism: A reconstruction.

Covington, M. V. (2007). A motivational analysis of academic life in college. In The scholarship of teaching and learning in higher education: An evidence-based perspective (pp. 661729). Springer.

Eccles, J. S., \& Roeser, R. W. (2009). Schools, academic motivation, and stage-environment fit. Handbook of Adolescent Psychology. R

Eilam, B., \& Aharon, I. (2003). Students' planning in the process of selfregulated learning. Contemporary Educational Psychology, 28(3), 304334.

Elliott, S., Kratochwill, T., Littlefield, J., \& Travers, J. (1996). Educational psychology (2th). Dubuque: A Times Mirror Company. 
Friedlander, L. J., Reid, G. J., Shupak, N., \& Cribbie, R. (2007). Social support, self-esteem, and stress as predictors of adjustment to university among firstyear undergraduates. Journal of College Student Development, 48(3), 259-274.

Jackson, T., Weiss, K. E., Lundquist, J. J., \& Hooper, D. (2003). The impact of hope, procrastination, and social activity on academic performance of MidWestern collage students. Education, 124(2), 310-321.

Joseph, J. M., \& Joseph, J. A. (2001). The resilient child: Preparing today's youth for tomorrow's world. Da Capo Press.

Knaus, W. J. (2010). End procrastination now!: Get it done with a proven psychological approach. McGrawHill.

LePine, J. A., Colquitt, J. A., \& Erez, A. (2000). Adaptability to changing task contexts: Effects of general cognitive ability, conscientiousness, and openness to experience. Personnel Psychology, 53(3), 563-593.

Mooney, S. P., Sherman, M. F., \& Presto, C. T. L. (1991). Academic locus of control, self-esteem, and perceived distance from home as predictors of college adjustment. Journal of Counseling and Development: JCD, 69(5), 445.
Mutai, L. C. (2014). The influence of locus of control on employees' perceptions of the effectiveness of performance appraisal at Kenya Revenue Authority (Southern region). University of Nairobi.

Rakes, G. C., \& Dunn, K. E. (2010). The impact of online graduate students' motivation and self-regulation on academic procrastination. Journal of Interactive Online Learning, 9(1), 7893.

Ramsden, P. (2003). Learning to teach in higher education. Routledge.

Richardson, M., Abraham, C., \& Bond, R. (2012). Psychological correlates of university students' academic performance: a systematic review and meta-analysis. Psychological Bulletin, 138(2), 353.

Riduwan, M. B. A. (2006). Belajar Mudah Penelitian Untuk Guru-Karyawan dan Peneliti Pemula. Bandung: Alfabeta.

Skowronski, M., \& Mirowska, A. (2013). A manager's guide to workplace procrastination. SAM Advanced Management Journal, 78(3), 4.

Syah, M. (2012). Psikologi Belajar Cet. Ke12. Jakarta: RajaGrafindo Persada. 